\title{
TSUNAMI MENTAWAI 25 OKTOBER 2010 DAN DAMPAKNYA KINI TERHADAP PANTAI BARAT MENTAWAI
}

\section{TSUNAMI OF MENTAWAI ON 25 OCTOBER 2010 AND ITS TODAY IMPACT ON THE WEST COAST OF MENTAWAI}

\author{
Herdiana Mutmainah ${ }^{1, *}$, Dominika Wara Christiana ${ }^{2}$, Gunardi Kusumah ${ }^{1}$ \\ ${ }^{1}$ Loka Penelitian Sumber Daya dan Kerentanan Pesisir, KKP, Komp. PPS Bungus, Jl. Raya \\ Padang Painan KM 16, Padang, Sumatera Barat 25245 \\ 2Program Studi Oseanografi, Institut Teknologi Bandung \\ ${ }^{*}$ Corresponding author e-mail: herdianam@yahoo.com
}

Submitted: 29 Oktober 2016 / Revised: 29 Oktober 2016 / Accepted: 31 Oktober 2016

DOI: http://dx.doi.org/10.21107/jk.v9i2.1917

\begin{abstract}
Tsunami that occurred on October 25, 2010 in Mentawai caused by the subduction of IndoAustralian plate and the Eurasian. An earthquake with a magnitude of 7.7 MW occurred at 14:42:22 UTC, or 21:42:22 pm with the epicenter at 3.484 locations ${ }^{\circ}$ LS and $100.114^{\circ} \mathrm{BT}$, at a depth of 20.6 kilometers in the Indian Ocean and is 280 kilometers from Padang or 110 kilometers of North Pagai. This earthquake was classified as a tsunami earthquake seaquake that generate big enough tsunami waves. Tsunami simulation was performed using 1.7 COMCOT with cesarean parameter strike $325^{\circ}$, dip $11,62^{\circ}$, and slip $101.4625^{\circ}$. The simulation results show that the tsunami height at six points ranging from 3.4 to 4.3 meters. This model calculates wave propagation up to the shoreline using linear equations. 2010 Tsunami impact on the West coast of the Mentawai include changes in the coastline that is severe abrasion on a small island and the loss of the region as well as several species of mangrove.
\end{abstract}

Keywords: Tsunami earthquake, the fault parameters, Mentawai Tsunami

\section{ABSTRAK}

Tsunami yang terjadi pada 25 Oktober 2010 di Mentawai disebabkan oleh subduksi lempeng IndoAustralia dan Eurasia. Gempa dengan magnitude 7.7 MW ini terjadi pada pukul 14:42:22 UTC atau 21:42:22 WIB dengan lokasi episenter di $3.484^{\circ} \mathrm{LS}$ dan 100.114 ${ }^{\circ} \mathrm{BT}$, pada kedalaman 20.6 kilometer di Samudera Hindia dan berjarak 280 kilometer dari Padang atau 110 kilometer dari Pagai Utara. Gempa ini tergolong tsunami earthquake karena merupakan gempa dasar laut yang menghasilkan gelombang tsunami cukup besar. Simulasi tsunami dilakukan menggunakan COMCOT 1.7 dengan parameter sesar strike $325^{\circ}$, dip $11,62^{\circ}$, dan slip $101.4625^{\circ}$. Hasil simulasi menunjukkan bahwa tinggi tsunami di enam titik berkisar 3.4 hingga 4.3 meter. Model ini menghitung penjalaran gelombang sampai ke garis pantai menggunakan persamaan linear. Dampak Tsunami tahun 2010 terhadap pantai Barat Mentawai berupa perubahan garis pantai yaitu abrasi parah pada pulau kecil dan hilangnya kawasan serta beberapa jenis mangrove.

Kata Kunci: Tsunami earthquake, parameter sesar, dampak Tsunami Mentawai

\section{PENDAHULUAN}

Tsunami adalah bencana alam di kawasan pesisir yang disebabkan oleh berbagai hal, salah satunya adalah gempa besar di dasar laut. Data statistik menunjukkan sejak tahun
1612 hingga 2000 sebanyak 118 kejadian Tsunami di Indonesia yang berdampak kerusakan fatal, $90 \%$ disebabkan oleh gempa di bawah laut, $9 \%$ vulkanik dan $1 \%$ tanah longsor (Latief et al., 2000). Sumatera Barat merupakan salah satu daerah yang 
sering mengalami gempa baik di darat maupun di laut karena lokasinya berada pada patahan Sumatera atau lempeng subduksi busur Sunda dan diantara 2 (dua) lempeng tektonik yaitu Eurasia dan Hindia-Australia. Kondisi batimetri laut dalam (Samudera Hindia) dan morfologi, serta topografi pantai atau kawasan pesisir memperbesar peluang terjadinya Tsunami. Shuto (1993), menyebutkan bahwa jarak jangkauan Tsunami ke daratan sangat ditentukan oleh tingkat kecuraman atau kelandaian pantai. Beberapa indikator yang mempengaruhi tingkat bahaya Tsunami diantaranya adalah landaan, kelerengan pantai, kekasaran pantai dan intensitas gempa bumi (Diposaptono dan Budiman, 2006). Tercatat bahwa Tsunami besar yang pernah terjadi di Padang yaitu pada tahun 1797 dan 1833 dengan ketinggian lebih dari 6 meter (McCloskey et al., 2008). Kepulauan Mentawai, merupakan salah satu kabupaten di Sumatera Barat yang sangat rawan terhadap gempa dasar laut. Pada Senin, 25 Oktober 2010 terjadi gempa dengan magnitude 7.7 MW di Samudera Hindia yang berdampak pada pantai barat Kepulauan Mentawai. Gempa terjadi akibat tumbukan lempeng Hindia-Australia dengan lempeng Eurasia sehingga menimbulkan patahan sepanjang $200 \mathrm{~km}$ di zona Megathrust Sunda (http://inatews.bmkg.go.id/). Menurut USGS, gempa terjadi pada pukul 14:42:22 UTC atau 21:42:22 waktu setempat dengan episenter di $3.484^{\circ}$ LS dan $100.114^{\circ}$ BT pada kedalaman 20.6 kilometer yang berjarak 110 $\mathrm{km}$ dari Pagai Utara, Kepulauan Mentawai. Tsunami pada tahun 2010 menyebabkan korban jiwa 428 orang meninggal, 74 orang hilang dan 498 orang luka-luka. Kerugian ditaksir sekitar Rp 6,8 M. 517 bangunan rusak berat dan 204 rumah rusak ringan (http://www.puailiggoubat.com). Penelitian oleh LIPI dan EOS tahun 2010 memperkirakan bahwa perairan Kepulauan Mentawai masih menyimpan potensi gempa dan Tsunami susulan sebesar 8,8 MW terutama daerah sekitar perairan Barat dan Timur Pulau Siberut hingga Pagai Utara (Natawidjaja, 2011). Hasil pemetaan indikator tingkat rawan gempa menggunakan AHP terhadap morfologi, topografi dan demografi di Pulau Pagai Utara menunjukkan pesisir barat tergolong rawan sedangkan pesisir timur sangat rawan (Setya, 2011). Namun pada kenyataannya, Tsunami Mentawai lebih berdampak pada kerusakan di pesisir Barat dibanding pesisir Timur. Hal ini disebabkan pesisir Timur cukup terlindung karena diapit oleh daratan Kepulauan Mentawai dan Pulau Sumatera, serta dibatasi oleh Selat Mentawai yang tidak terlalu lebar atau dalam dibanding Samudera Hindia di pesisir Barat.

Gempa Mentawai 2010 merupakan gempa berskala besar. Gempa tersebut terjadi akibat lempeng Hindia-Australia menabrak bagian barat Sumatra dengan kemiringan $12^{\circ}$ ke arah timur dengan kecepatan 50-60 $\mathrm{mm} /$ tahun (Natawidjaja, 2003; Prawirodirdjo, 2000) atau disebut zona subduksi dan menimbulkan dua arah tekanan yaitu tegak lurus dan sejajar palung ke arah barat laut sehingga menimbulkan patahan Sumatra di sepanjang Bukit Barisan (Sieh dan Natawidjajja, 2000). Pergerakan tersebut menyebabkan sesar naik di permukaan pada batas lempeng subduksi Hindia-Australia dan subduksi Megathrust Sunda. Pergerakan lempeng Hindia-Australia adalah ke arah timur laut terhadap Megathrust Sunda (Yudhicara et al., 2010).

Penelitian ini merupakan simulasi pemodelan Tsunami menggunakan COMCOT 1.7 dengan persamaan numerik linear koordinat bola untuk mengetahui penjalaran gelombang akibat sesar antara batas lempeng subduksi Hindia-Australia dan Eurasia yang dibandingkan dengan hasil penelitian Satake (2013) serta perubahan kondisi pantai barat Mentawai terkini yang rusak akibat Tsunami pada tahun 2010. 


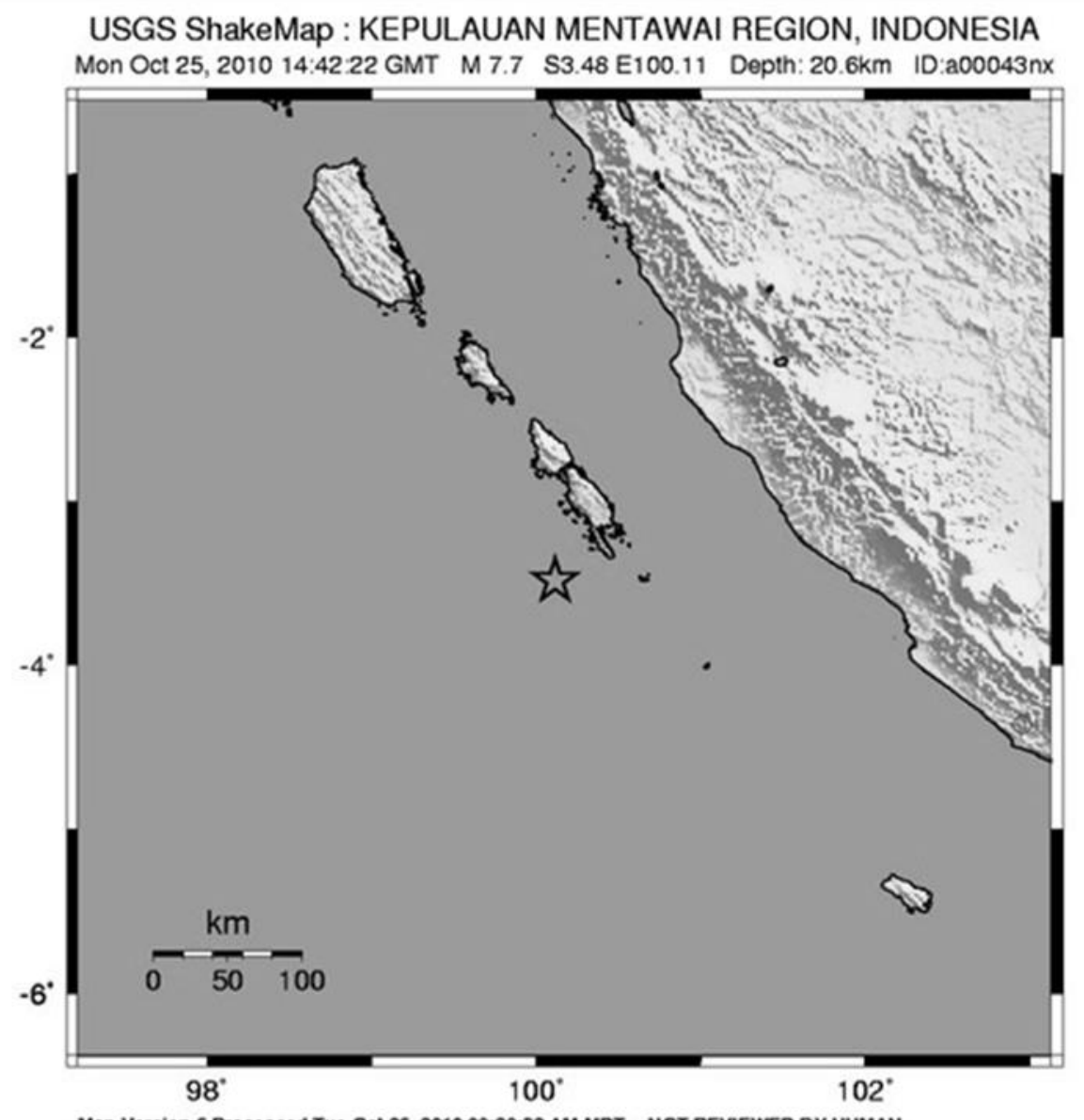

Map Version 6 Processed Tue Oct 26, 2010 09:29:32 AM MOT - NOT REVIEWED BY HUMAN

\begin{tabular}{|c|c|c|c|c|c|c|c|c|c|}
\hline PEg & Not felt & 1. Weak & Light & Moderate & Strong & Very strong & Severe & Violent & Extreme \\
\hline $\begin{array}{l}\text { POTENTIAL } \\
\text { DANAGEE }\end{array}$ & none & ono & nono & Vory light & ight & Moderate & ModorateHoavy & Hoavy & Vory Hoany \\
\hline PEAK ACC (\$S) & $<17$ & $.17-1.4$ & $1.4-3.9$ & $3.9-9.2$ & $9.2-18$ & $18 \cdot 34$ & $34-65$ & 65.124 & $>124$ \\
\hline PEAK VEL_(cm/a) & $<0.1$ & $0.1-1.1$ & $1.1-3.4$ & $3.4-8.1$ & 8.1 .16 & $16-31$ & 31.60 & $60-116$ & $>116$ \\
\hline \begin{tabular}{|c|} 
INSTRUNENTAL \\
INTENISITY \\
\end{tabular} & 1 & II-III & IV & v & VI & VII & VIII & $1 X$ & 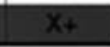 \\
\hline
\end{tabular}

Sumber: USGS, 2015

Gambar 1. Lokasi gempa di Kepulauan Mentawai 25 Oktober 2010

\section{MATERI DAN METODE}

Metode yang digunakan adalah survey primer berupa wawancara, dokumentasi, pengambilan substrat dasar perairan menggunakan sediment grab dan ground truthing menggunakan GPS serta survey sekunder berupa peta bathimetri Dishidros, $\mathrm{RBI}$, peta google earth, dan GEBCO. Penelitian ini dilakukan pada 4 hingga 8 April
2016 di pantai barat Pulau Pagai Utara, Kabupaten Kepulauan Mentawai dan pulaupulau kecil disekitarnya. Adapun persamaan pembangun yang digunakan dalam COMCOT 1.7 pada kasus ini adalah persamaan linear untuk fungsi ketinggian run up dan waktu penjalaran Tsunami untuk koordinat bola. Persamaan-persamaan yang digunakan adalah sebagai berikut:

$$
\begin{aligned}
\frac{\partial \eta}{\partial t}+\frac{1}{R \cos \varphi}\left\{\frac{\partial P}{\partial \psi}+\frac{\partial}{\partial \varphi}(\cos \varphi Q)\right\} & =-\frac{\partial h}{\partial t} \\
\frac{\partial P}{\partial t}+\frac{g h}{R \cos \varphi} \frac{\partial \eta}{\partial \psi}-f Q & =0
\end{aligned}
$$




$$
\frac{\partial Q}{\partial t}+\frac{g h}{R} \frac{\partial \eta}{\partial \varphi}+f P=0
$$

$\eta$ adalah elevasi permukaan air, $(P, Q)$ fluks volume pada arah $X$ dan $Y,(\varphi, \psi)$ lintang dan bujur Bumi, R adalah jari-jari Bumi, g adalah percepatan gravitasi dan $h$ adalah kedalaman air. $\mathrm{f}$ merepresentasikan koefisien gaya Coriolis akibat rotasi Bumi.
Daerah Kajian yang digunakan pada pemodelan ini adalah mencakup kawasan 1$5^{\circ}$ LS dan $98-102^{\circ}$ BT. Data batimetri daerah kajian pada gambar 2 ditampilkan menggunakan Gebco 30 detik.

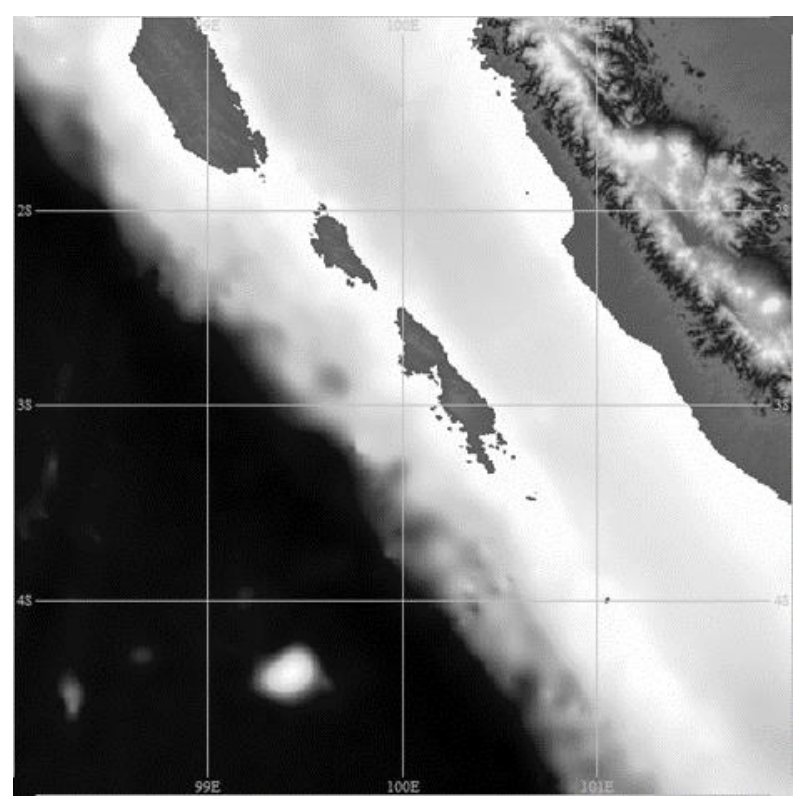

Sumber: Gebco

Gambar 2. Daerah kajian model

Skenario yang digunakan untuk simulasi tsunami adalah seperti dalam Tabel 1 berikut ini.

Tabel 1. Parameter sesar sebagai skenario simulasi

\begin{tabular}{|c|c|c|c|c|c|c|c|c|c|c|c|}
\hline \multicolumn{2}{|c|}{ Epicenter } & \multirow{2}{*}{$\begin{array}{c}\text { Focal } \\
\text { depth } \\
(\mathrm{km})\end{array}$} & \multirow{2}{*}{$\begin{array}{c}\text { Length } \\
(\mathrm{km})\end{array}$} & \multirow{2}{*}{$\begin{array}{c}\text { Width } \\
(\mathrm{km})\end{array}$} & \multirow{2}{*}{$\begin{array}{l}\text { Disloc } \\
\text { ation } \\
(m)\end{array}$} & \multirow{2}{*}{$\begin{array}{c}\text { Strike } \\
\left({ }^{\circ}\right)\end{array}$} & \multirow{2}{*}{$\begin{array}{l}\text { Dip } \\
\left({ }^{\circ}\right)\end{array}$} & \multirow[b]{2}{*}{$\begin{array}{c}\text { Slip } \\
\left({ }^{\circ}\right)\end{array}$} & \multirow{2}{*}{$\begin{array}{c}\text { Total } \\
\text { runtime } \\
\text { (s) }\end{array}$} & \multirow{2}{*}{$\begin{array}{l}D t \\
(s)\end{array}$} & \multirow{2}{*}{$\begin{array}{c}D x \\
\text { (menit) }\end{array}$} \\
\hline $\begin{array}{l}\text { Lat. } \\
\left({ }^{\circ} S\right)\end{array}$ & $\begin{array}{l}\text { Lon } \\
\left({ }^{\circ} E\right)\end{array}$ & & & & & & & & & & \\
\hline $\begin{array}{c}3.46 \\
4\end{array}$ & $\begin{array}{c}100.1 \\
1\end{array}$ & 20.6 & 190 & 70 & 12.088 & 325 & $11.62^{\circ}$ & $101.4625^{\circ}$ & 1800 & 1 & 0.5 \\
\hline
\end{tabular}

(Sumber: USGS, 2015)

\section{HASIL DAN PEMBAHASAN}

Gempa Mentawai 2010 merupakan tsunami earthquake atau slow earthquake karena meskipun getaran yang sampai di darat terasa lemah dan periode gempa cukup lama (lebih dari 1 menit), namun menimbulkan gelombang tsunami sangat besar terutama di
Pulau Sibigiu, sebelah selatan Pagai Utara yang mencapai ketinggian hingga 17 meter (Natawidaja, 2011) dan mengakibatkan hilangnya Pulau Sibigiu tersebut. Berikut ini adalah hasil dari pemodelan yang telah dilakukan menggunakan COMCOT1.7 (Gambar 3) dan letak Pulau Sibigiu (Gambar 4). 


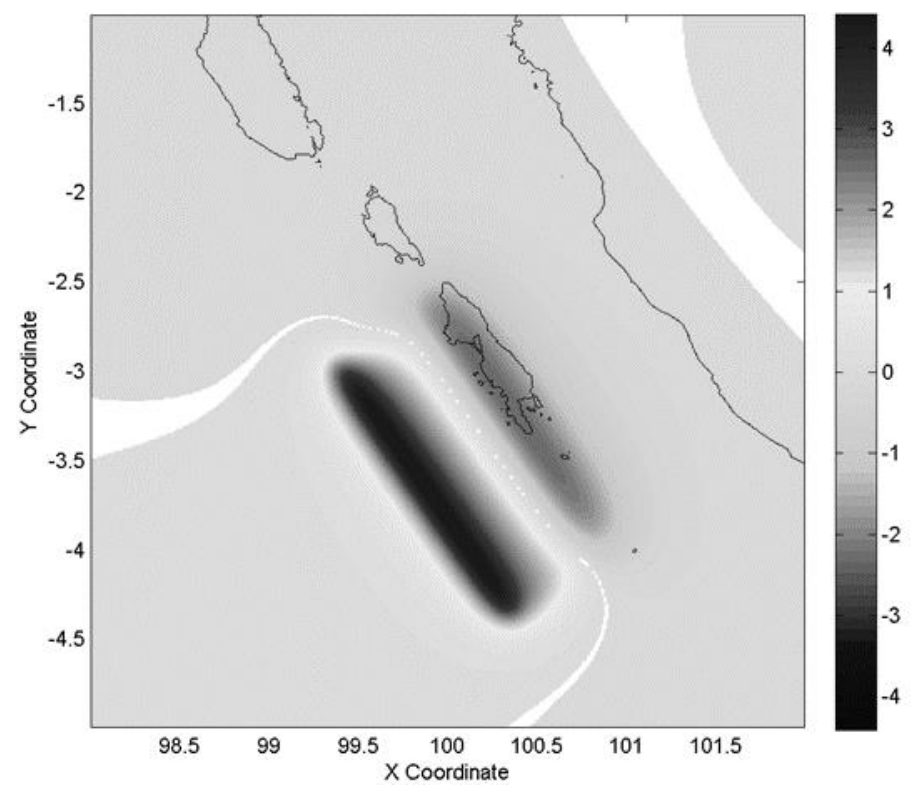

Gambar 3. Kondisi awal pergerakan dasar laut akibat tumbukan lempeng subduksi

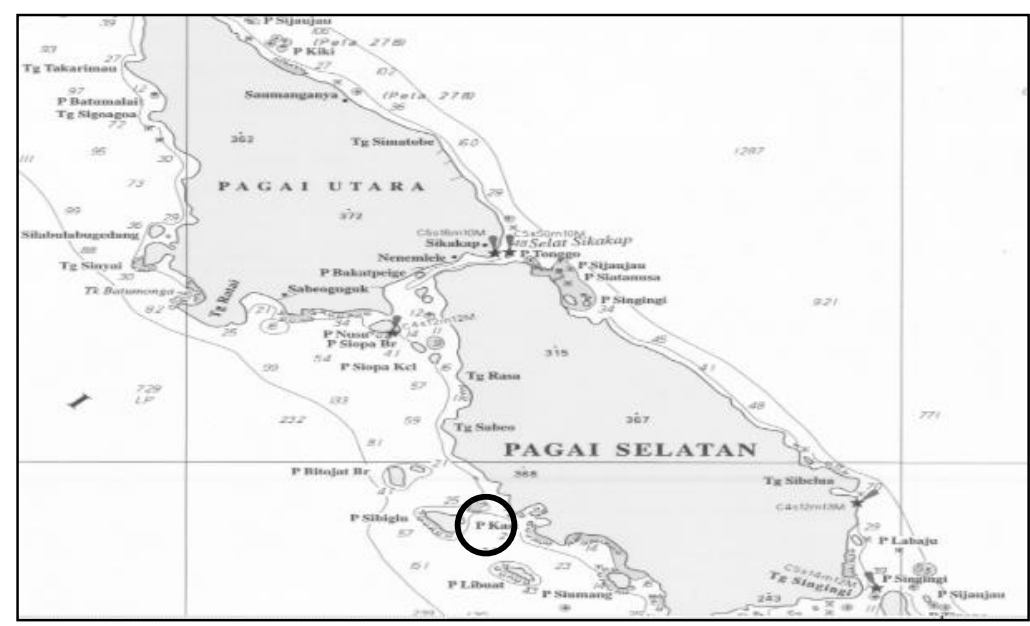

Gambar 4. Letak Pulau Sibigue

Gambar 3 menunjukkan kondisi awal pada saat terjadi gempa Mentawai pada 25 Oktober 2010 pukul 14:42:22 UTC dengan skala magnitude 7.7 MW. Gambar kondisi awal menunjukkan kondisi land subsidence. Kondisi land subsidence dipengaruhi oleh berbagai parameter fault atau retakan seperti dislokasi, rake, dip, dan strike. Berdasar simulasi yang dilakukan, semakin besar dislokasi, maka semakin besar land subsidence. Adanya proses land subsidence menyebabkan gangguan vertikal pada kolom air di atasnya. Gangguan inilah yang kemudian mengawali terjadinya tsunami. Nilai zmax atau tinggi maksimum yang terbentuk pada kondisi awal adalah 4.6 meter di sepanjang bidang fault.
Hasil simulasi menunjukkan adanya perpindahan massa air yang cukup besar sehingga bertransformasi menjadi tsunami yang besar. Simulasi dilakukan untuk total waktu 30 menit. Rentang waktu ini ditentukan dengan alasan bahwa berdasarkan penelitian sebelumnya (Ibad dan Santosa, 2014), tsunami dilaporkan mencapai pesisir Pulau Pagai Utara dalam waktu 16 menit 40 detik setelah gempa terjadi. Konfirmasi berdasarkan penelitian lapangan dibutuhkan untuk mengetahui kejadian sebenarnya berkaitan dengan waktu tiba dan tinggi gelombang tsunami. 


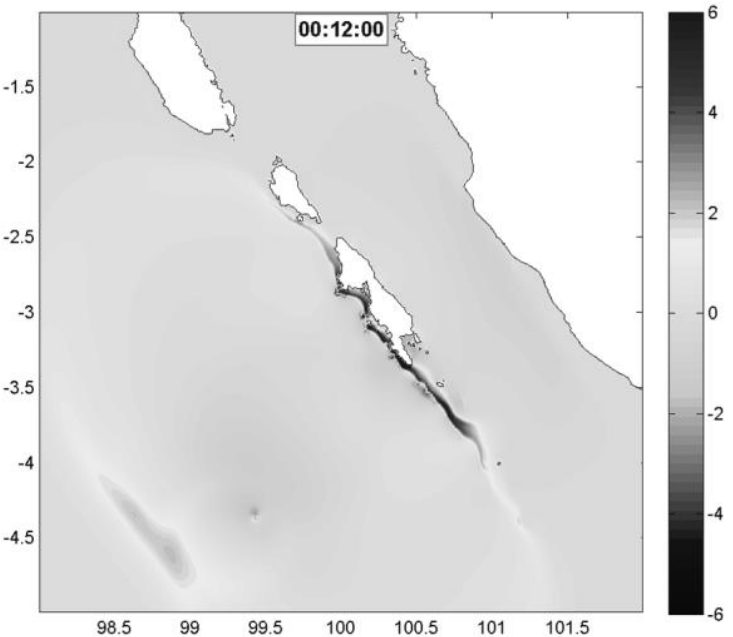

(a)

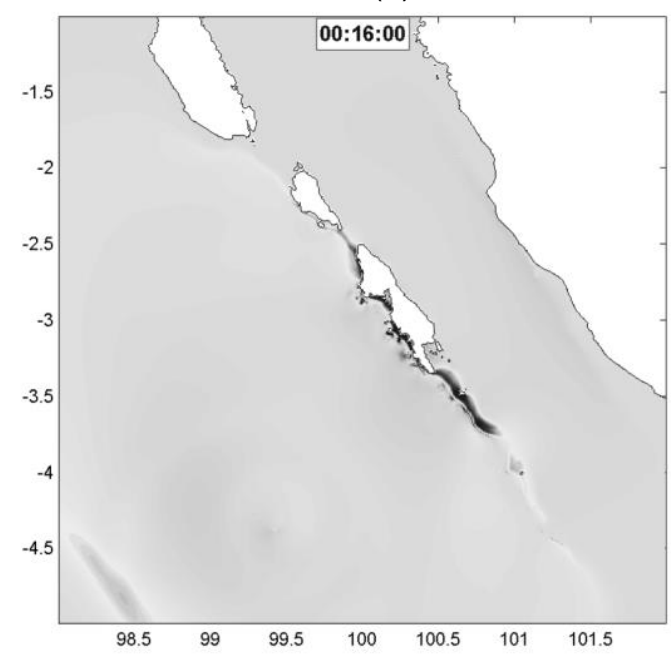

(c)

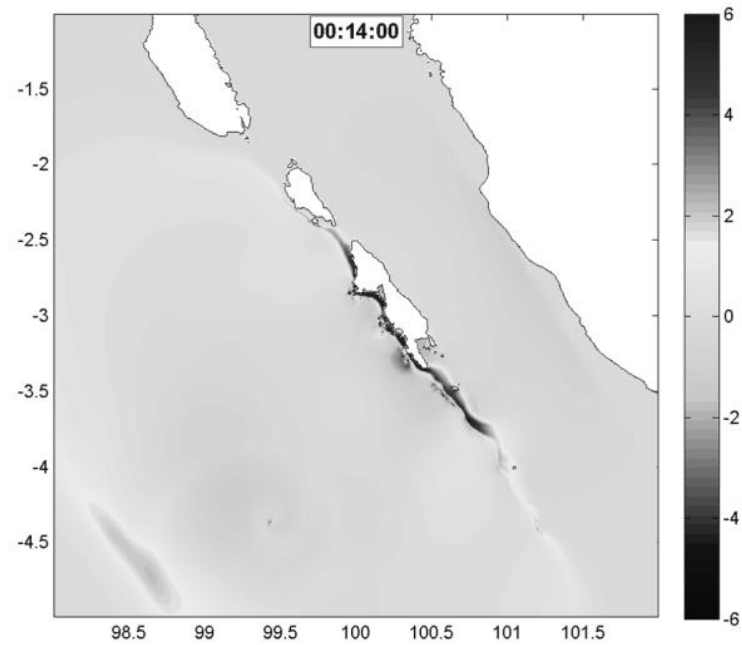

(b)
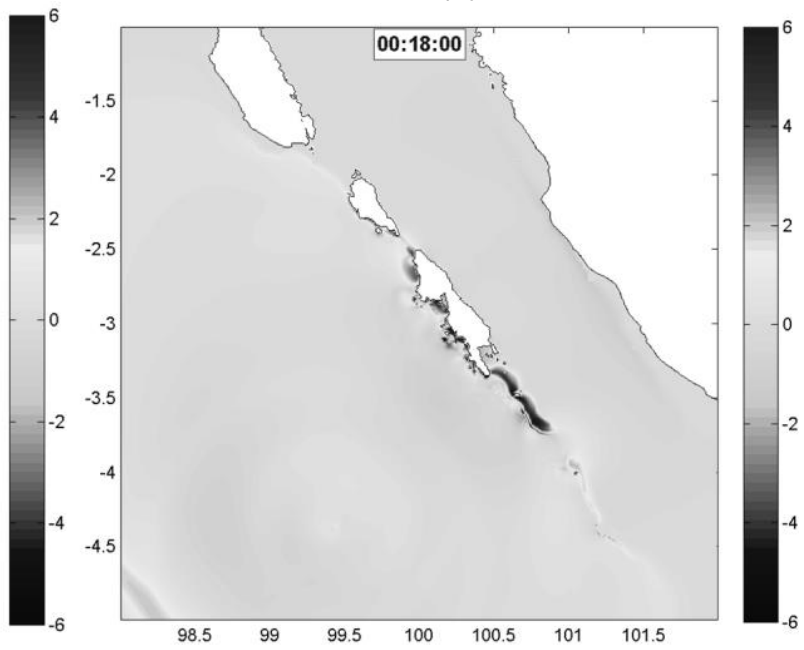

(d)

Gambar 5. Penjalaran Tsunami pada menit ke- (a) 12, (b) 14, (c) 16 dan (d) 18 setelah gempa

Gambar 5 menunjukkan penjalaran tsunami nearfield ke arah pesisir barat Pulau Pagai Utara. Berdasar hasil simulasi, tsunami mencapai pesisir Pulau Pagai Utara dan
Selatan pada menit ke 14 . Untuk melihat tinggi gelombang di dekat pantai, digunakan plot time series elevasi di enam titik.

Tabel 2. Ketinggian Tsunami hasil simulasi COMCOT 1.7

\begin{tabular}{|c|c|c|c|c|}
\hline \multirow[b]{2}{*}{ Titik } & \multicolumn{2}{|c|}{ Koordinat } & \multirow{2}{*}{$\begin{array}{l}\text { Elevasi maksimum } \\
\qquad(\mathrm{m})\end{array}$} & \multirow{2}{*}{$\begin{array}{c}\text { Waktu } \\
\text { (menit:detik) }\end{array}$} \\
\hline & $\begin{array}{c}\text { Lintang } \\
\left({ }^{\circ} \text { LS }\right)\end{array}$ & $\begin{array}{l}\text { Bujur } \\
\left({ }^{\circ} \mathrm{BT}\right)\end{array}$ & & \\
\hline A & 2.5747 & 99.9247 & 3.5 & $13: 49$ \\
\hline B & 2.6814 & 99.9592 & 3.6 & 18:06 \\
\hline C & 2.7607 & 99.9430 & 3.4 & $9: 41$ \\
\hline D & 2.8896 & 100.0582 & 4.3 & $11: 48$ \\
\hline E & 2.6419 & 99.9257 & 3.0 & $18: 44$ \\
\hline $\mathrm{F}$ & 2.7891 & 99.9474 & 3.7 & $9: 33$ \\
\hline
\end{tabular}


Pada keenam titik tinjauan, elevasi maksimum dicapai pada waktu yang berbeda. Titik A mencapai elevasi maksimum 3.5 meter pada 13 menit 49 detik, titik B 3.6 meter pada 18 menit 6 detik, titik $C 3.4$ meter pada 9 menit 41 detik, titik $D 3$ meter pada 18 menit 44 detik dan titik $\mathrm{F}$ pada 9 menit 33 detik. Gambar 6 berikut ini menunjukkan lokasi keenam titik tinjauan di barat pantai Pulau Pagai Utara, Mentawai.

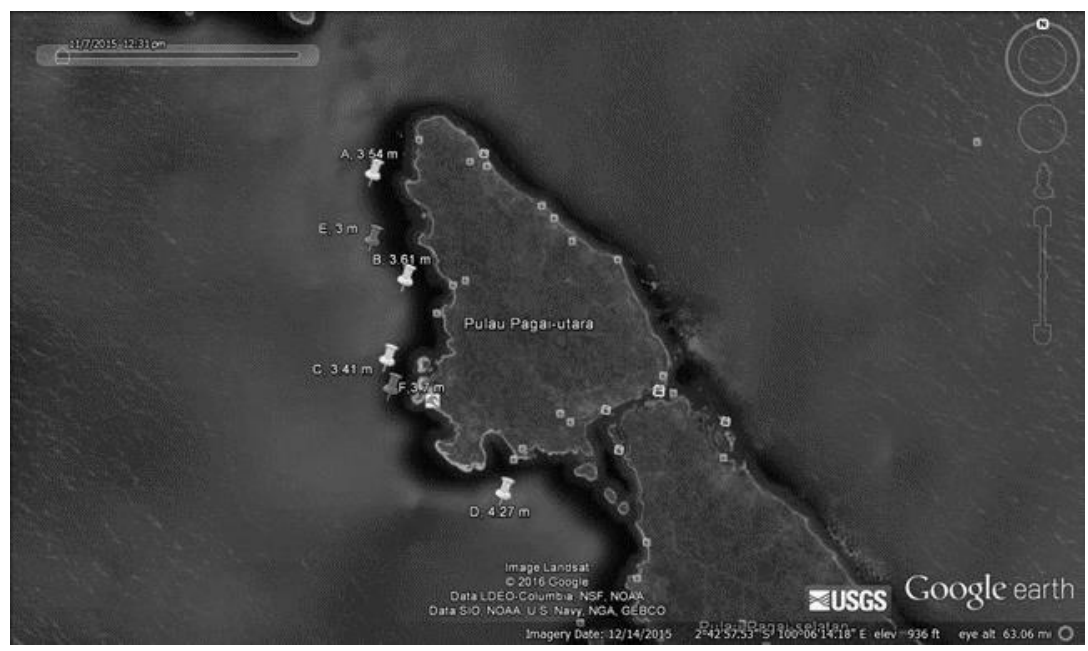

Gambar 6. Keenam titik tinjauan simulasi di Pulau Pagai Utara

Gambar 7 berikut menunjukkan ketiga titik simulasi yaitu $D, E, F$ yang dipilih karena letaknya paling dekat dengan lokasi pengamatan di garis pantai tempat dilakukannya pengukuran oleh penelitian sebelumnya yaitu Satake pada tahun 2013.

Adapun hasil simulasi seperti tercantum dalam Tabel 3.

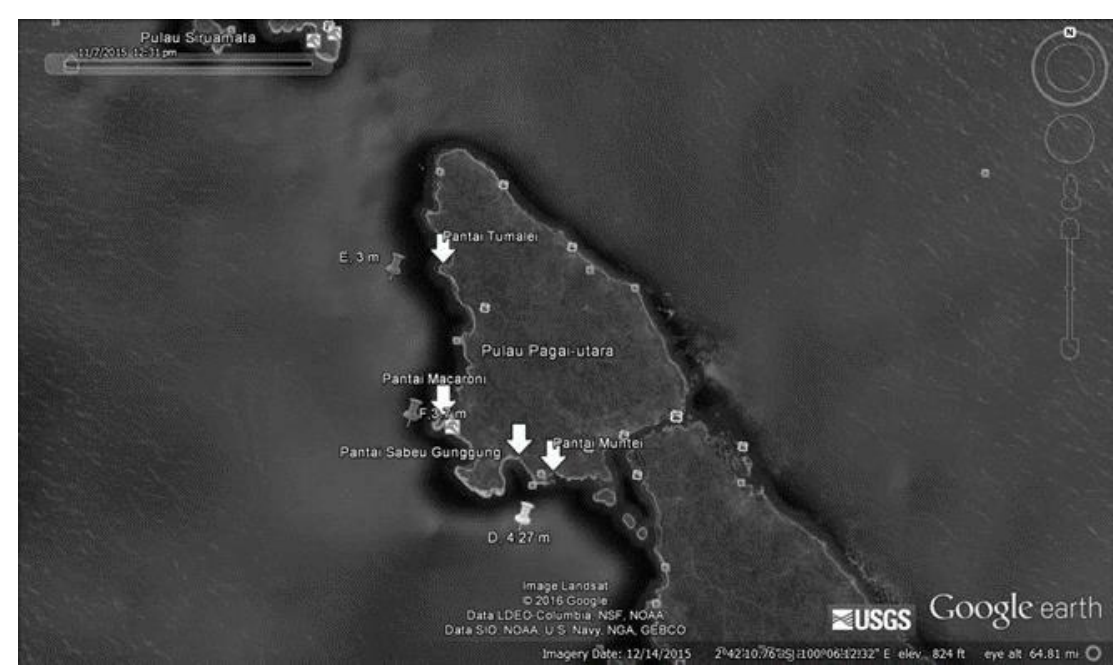

Keterangan : Google earth modifikasi

Gambar 7. Titik Simulasi (D, E, F) dan titik pengukuran Satake, 2013 (tanda panah putih) di Pantai Barat Pagai Utara, Mentawai 
Tabel 3. Ketinggian Tsunami hasil simulasi COMCOT 1.7 dan pengamatan Satake (2013).

\begin{tabular}{|c|c|c|c|c|c|}
\hline \multicolumn{3}{|c|}{ Hasil Model } & \multicolumn{3}{|c|}{ Survei Lapangan (rata-rata) Satake } \\
\hline Lokasi & $\begin{array}{c}\text { Koordinat } \\
\left({ }^{\circ} \text { LS dan }{ }^{\circ} \text { BT }\right) \\
\end{array}$ & $\begin{array}{c}\text { Tinggi } \\
\text { tsunami } \\
(\mathrm{m})\end{array}$ & Lokasi di garis pantai & $\begin{array}{c}\text { Koordinat } \\
\left({ }^{\circ} \text { LS dan }{ }^{\circ} \text { BT }\right)\end{array}$ & $\begin{array}{c}\text { Tinggi } \\
\text { tsunami } \\
(\mathrm{m})\end{array}$ \\
\hline Titik E & $\begin{array}{r}2.8896^{\circ} \mathrm{LS}, \\
100.0582^{\circ} \mathrm{BT}\end{array}$ & 3.0 & Pantai Tumelei (E') & $\begin{array}{r}2.62417^{\circ} \mathrm{LS}, \\
99.97917^{\circ} \mathrm{BT}\end{array}$ & 5.1 \\
\hline Titik F & $\begin{array}{l}2.6419^{\circ} \mathrm{LS}, \\
99.9257^{\circ} \mathrm{BT}\end{array}$ & 3.7 & Pantai Macaroni (F') & $\begin{array}{l}2.77806^{\circ} \mathrm{LS}, \\
99.98278^{\circ} \mathrm{BT}\end{array}$ & 4.0 \\
\hline \multirow{2}{*}{ Titik D } & \multirow{2}{*}{$\begin{array}{l}2.7891^{\circ} \mathrm{LS}, \\
99.9474^{\circ} \mathrm{BT}\end{array}$} & \multirow{2}{*}{4.3} & $\begin{array}{l}\text { Pantai Sabeu } \\
\text { Gunggung }\left(\mathrm{D}_{1}{ }^{\prime}\right)\end{array}$ & $\begin{array}{r}2.81639^{\circ} \mathrm{LS}, \\
100.05806^{\circ} \mathrm{BT}\end{array}$ & 5.5 \\
\hline & & & Pantai Muntei $\left(\mathrm{D}_{2}{ }^{\prime}\right)$ & $\begin{array}{r}2.83222^{\circ} \mathrm{LS}, \\
100.09167^{\circ} \mathrm{BT}\end{array}$ & 5.6 \\
\hline
\end{tabular}

Berdasarkan hasil simulasi, tinggi tsunami di titik $E, F$, dan $D$ lebih rendah dibandingkan dengan tinggi tsunami di pantai terdekat ( $\mathrm{E}^{\prime}$, $\left.F^{\prime}, D_{1}{ }^{\prime} D_{2}{ }^{\prime}\right)$ hasil penelitian Satake (2013). Bertambahnya tinggi gelombang yang mendekati garis pantai dapat mencapai selisih 1 hingga lebih dari 2 meter dipengaruhi oleh kontur batimetri yang dangkal. Tingkat keparahan terjadi di daerah selatan kemudian semakin berkurang ke arah utara. Daerah selatan yaitu Muntei dan Sabeugunggung merupakan daerah yang

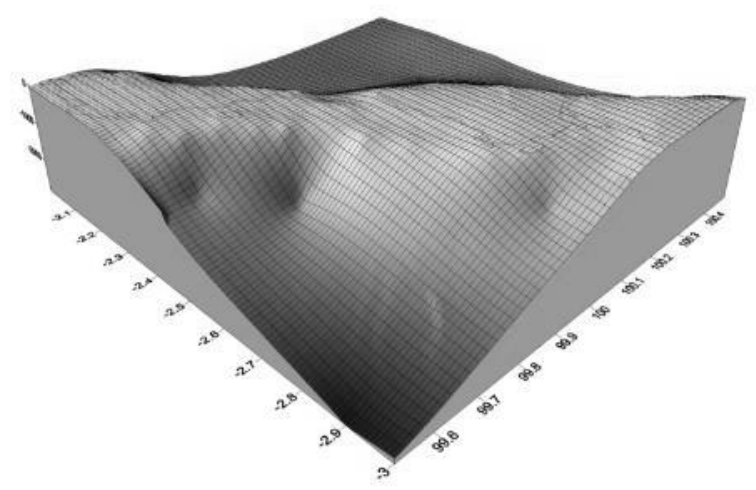

cukup parah terkena Tsunami, disusul Macaronis dengan pantai yang sangat landai kemudian Tumelei, tidak terlalu parah karena terlindung oleh Macaronis. Tumelei juga memiliki jarak jangkau Tsunami yang lebih jauh sehingga menyebabkan energi Tsunami berkurang dan memperkecil hantaman Tsunami dibanding ketiga lokasi lainnya. Gambar 8 berikut adalah peta kontur kedalaman atau batimetri perairan Pagai Utara.

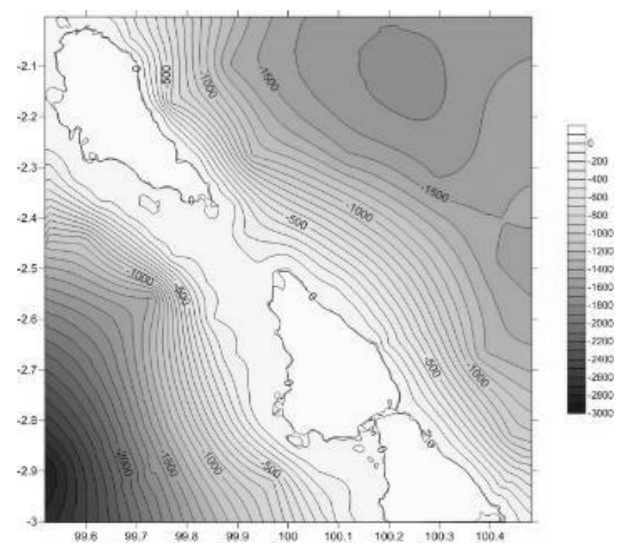

Gambar 8. Peta Kontur Batimetri Pagai Utara

\section{Perubahan Mangrove}

Gambar 9 menunjukkan dampak Tsunami terhadap hilangnya kawasan mangrove yang cukup luas di salah satu pantai yaitu Macaronis. Kawasan mangrove tersebut yaitu A seluas $1.633 \mathrm{~m}^{2}$, B seluas $6.457 \mathrm{~m}^{2}$, C seluas $2.375 \mathrm{~m}^{2}$, dan $D$ seluas $1.565 \mathrm{~m}^{2}$ dengan total luas $12.030 \mathrm{~m}^{2}$ atau 1,2 Hektar. Berdasarkan keterangan warga setempat, dulunya tempat ini merupakan kawasan surfing yang cukup terkenal dengan resort dan berbagai jenis mangrove disekitarnya. Namun setelah Tsunami 2010, kawasan ini menjadi sepi pengunjung dan mangrove juga lebih sedikit. Hanya tinggal 2 (dua) jenis mangrove di kawasan ini yaitu Rhizophora Apiculata (Stasiun 1 dan Stasiun 2) dan Bruguiera Gymnorrhiza (Stasiun 2) dengan tingkat kerapatan $50 \%$ hingga $75 \%$ dan tutupan sedang (Gambar 10). 


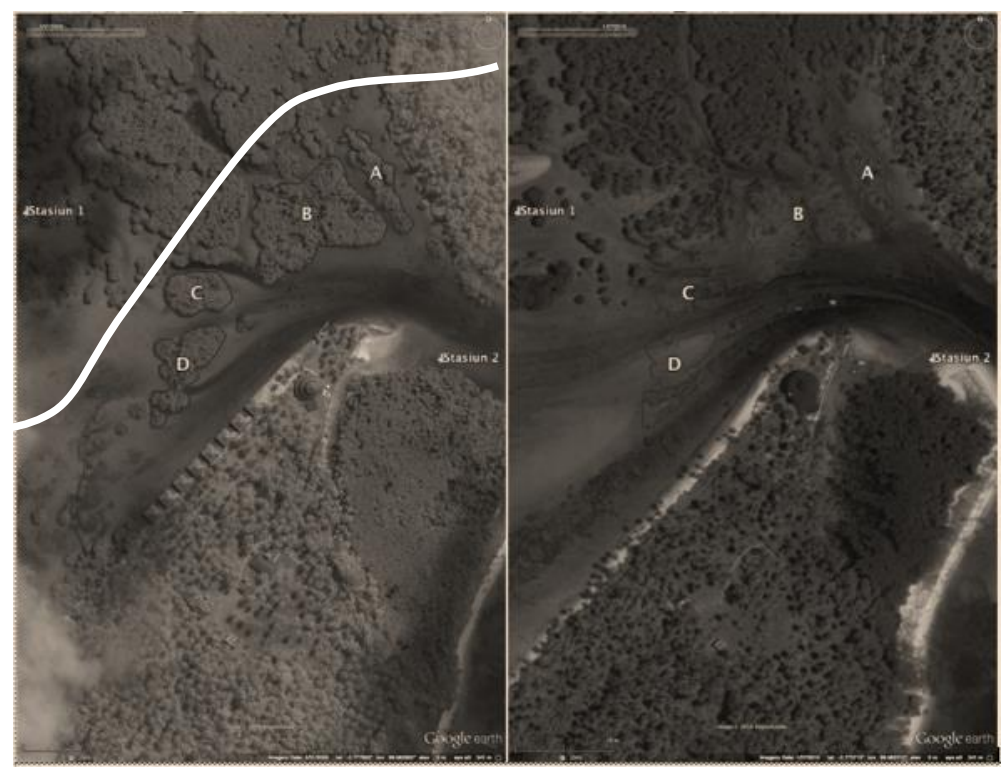

(a) Macaronis Tahun 2009

(b) Macaronis Tahun 2015

Gambar 9. Kawasan mangrove yang hilang di kawasan Macaronis (A, B, C dan D):

(a) sebelum Tsunami, (b) setelah Tsunami

Berdasarkan hasil pengamatan, dapat disimpulkan bahwa jenis Rhizopora Apiculata yang tumbuh di perairan dengan substrat pasir memiliki daya tahan cukup baik terhadap Tsunami yang memiliki tinggi gelombang sekitar 3 hingga 4 meter pada tahun 2010.

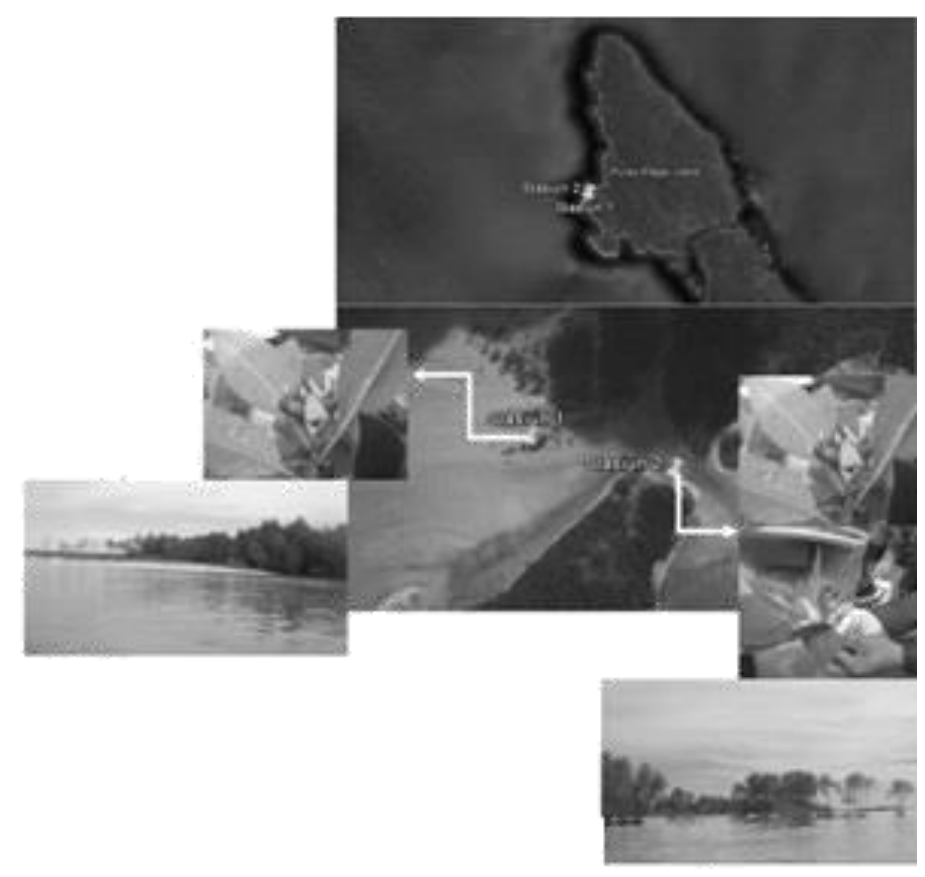

Gambar 10. Lokasi survey mangrove di Macaronis

\section{Abrasi Pulau Ragi}

Berdasarkan gambar 11 terjadi perubahan luasan di Pulau Ragi akibat abrasi selama 7 tahun yaitu sejak tahun 2008 hingga 2015 dengan laju perubahan $1.075 \mathrm{~m}^{2} /$ tahun atau $0,11 \mathrm{Ha}$ /tahun. Berdasarkan wawancara dengan penduduk, Pulau Ragi merupakan salah satu pulau kecil yang terkena Tsunami cukup parah pada tahun 2010. Tampak dalam gambar di atas, pecahan-pecahan kerang di atas hamparan pasir berbutir sangat halus. Pasir di Pulau Ragi adalah 
sama dengan jenis pasir yang ada di Pantai Macaronis. Pulau Ragi merupakan pulau dengan topografi yang cukup flat $(<50$ meter dpl), kedalaman perairan berkisar antara 5 hingga 7 meter dan vegetasi berupa mangrove. Perubahan arah garis pantai di ujung pulau (tanpa vegetasi) mengikuti kedalaman kontur bathimetri (mengarah pada kedalaman 11 meter) ke arah arus dominan yaitu timur laut. Gambar 12 (a) dan (b) menunjukkan letak Pulau Ragi terhadap Pulau Pagai Utara dan (c) topografi dan batimetri di Pulau Ragi.
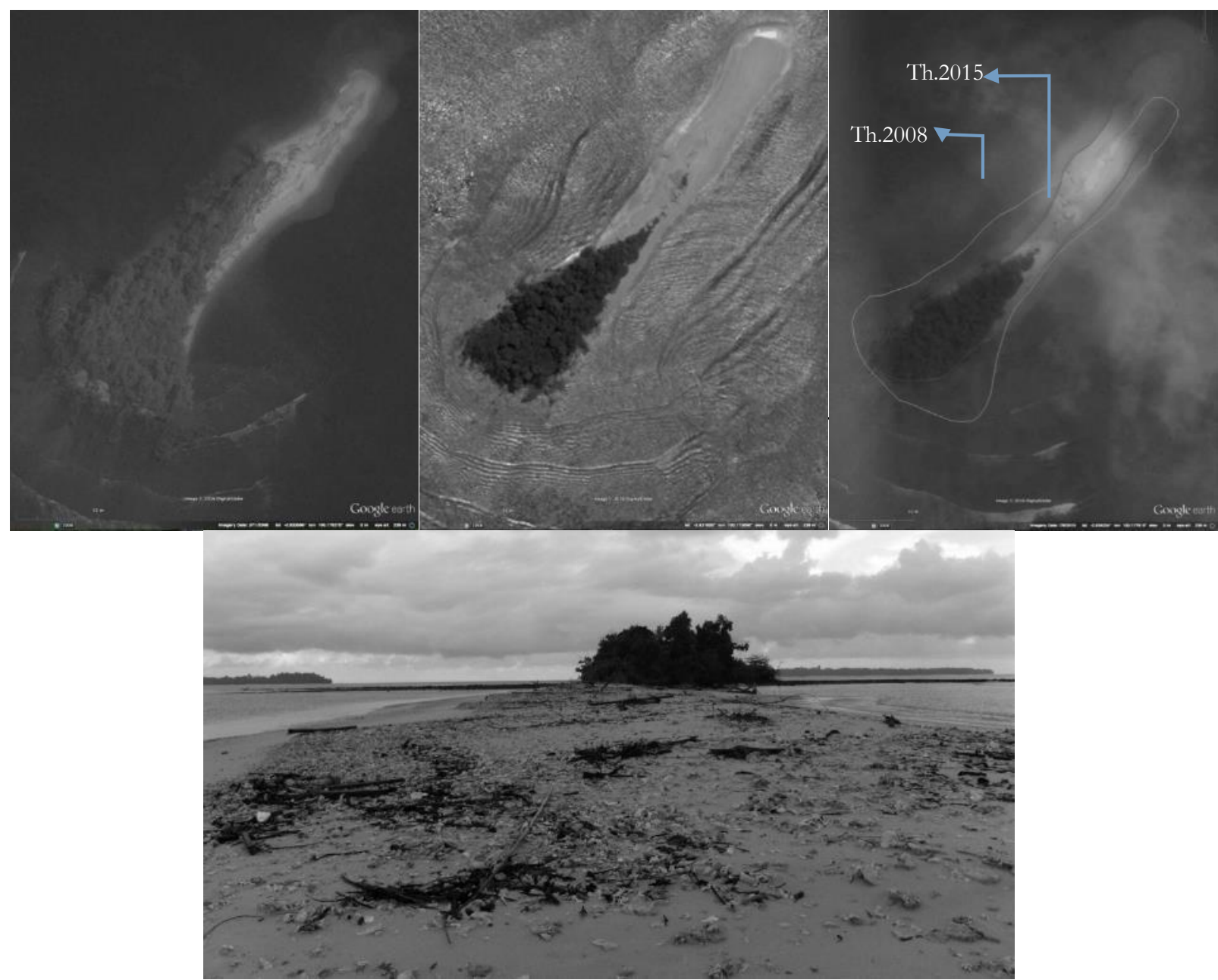

Gambar 11. Abrasi cukup parah di Pulau Ragi akibat Tsunami tahun 2010

Tsunami menjadi ancaman terbesar bagi pulau-pulau kecil. Tsunami dengan kekuatan $7,7 \mathrm{MW}$ dan tinggi gelombang lebih dari 5 meter di Mentawai terbukti tidak hanya menimbulkan abrasi yang parah tetapi juga hilangnya kawasan dan jenis mangrove. Relokasi dan perubahan mata pencaharian penduduk menjadi dampak ikutan untuk kawasan yang terkena Tsunami sehingga menjadi pekerjaan rumah bagi pemerintah daerah setempat yang harus segera ditangani. Selama enam tahun sejak terjadinya Tsunami di Mentawai, kawasan ini belum dapat pulih sepenuhnya secara alami. 


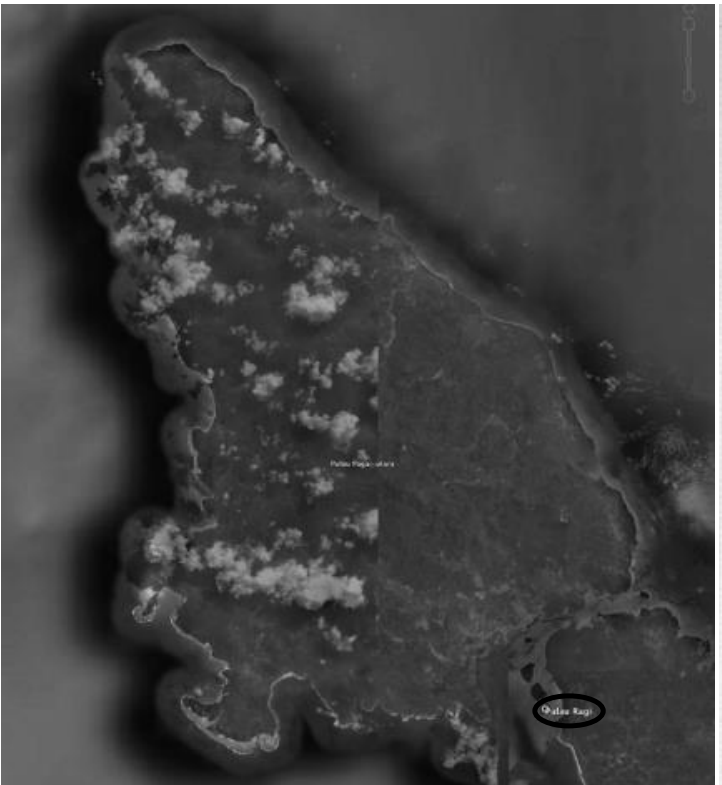

(a) Pulau Ragi (Google earth)

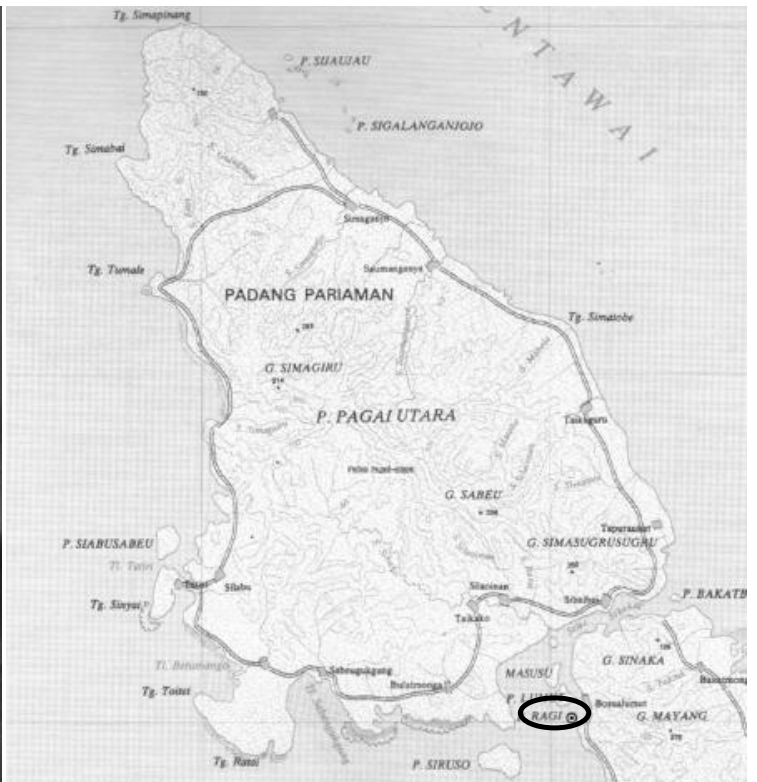

(b) Topografi Pulau Ragi (Peta RBI)

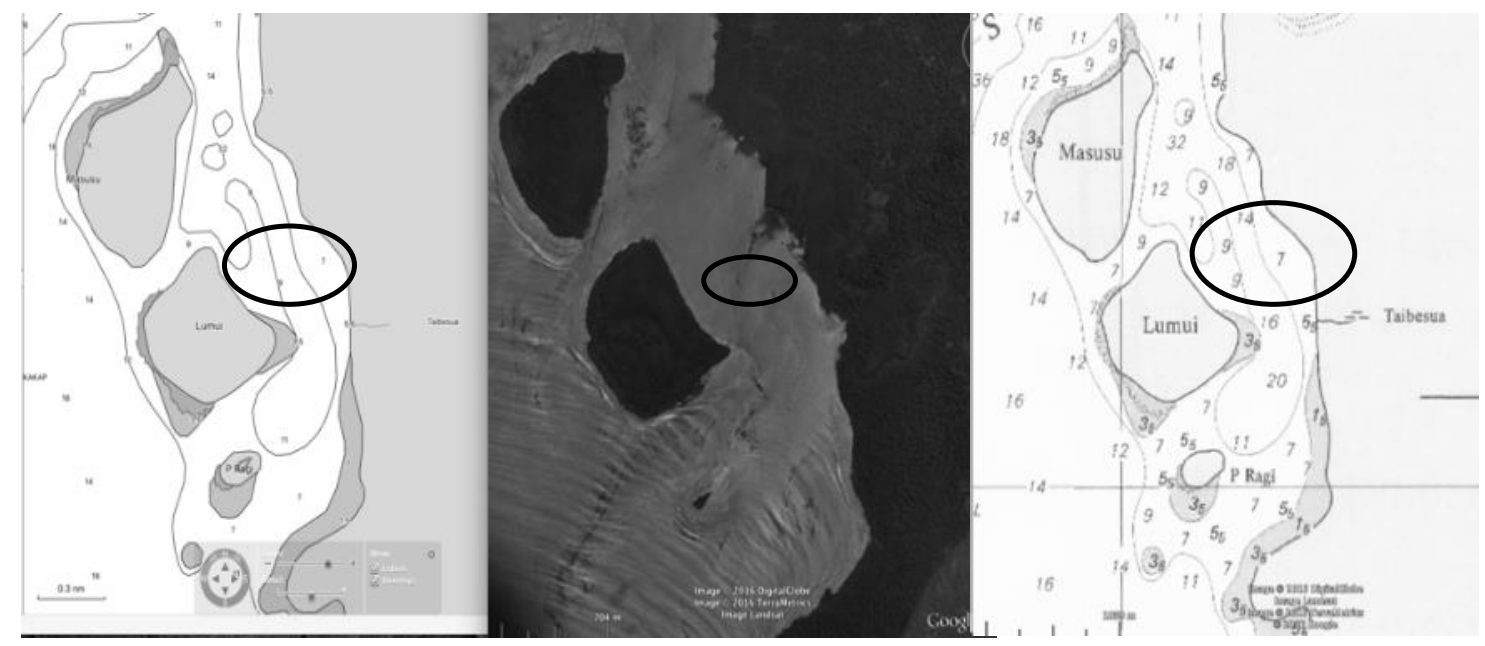

(c) Batimetri Pulau Ragi (Peta Dishidros)

Gambar 12. Peta Topografi dan Batimetri Pulau Ragi

\section{KESIMPULAN DAN SARAN}

1. Tsunami Mentawai 2010 merupakan tsunami earthquake, yaitu gempa dengan getaran lemah namun menghasilkan tsunami besar.

2. Berdasarkan hasil simulasi keenam titik tinjauan di barat Pulau Pagai Utara, tinggi tsunami berkisar antara 3.4-4.3 meter dengan waktu penjalaran selama 9-18 menit.

3. Dampak Tsunami Mentawai 2010 berakibat pada abrasi parah pada Pulau Ragi dan hilangnya kawasan mangrove yang cukup luas serta berkurangnya jenis mangrove di Pantai Macaronis.
4. Saran bagi pemerintah daerah setempat untuk membangun bangunan pelindung pantai dan greenbelt untuk mencegah kerusakan pantai yang lebih parah.

\section{UCAPAN TERIMA KASIH}

Ucapan terima kasih disampaikan kepada Kepala Loka Penelitian Sumber Daya dan Kerentanan Pesisir di Bungus, Balitbang Kementerian Kelautan dan Perikanan di Jakarta, Institut Teknologi Bandung, Universitas Gadjah Mada, Pemerintah Daerah Provinsi Sumatera Barat, Pemerintah Daerah Kabupaten Kepulauan Mentawai, Institusi Perguruan Tinggi di Sumatera Barat (Universitas Andalas dan Universitas Bung 
Hatta), dan lain-lain yang terlibat secara langsung maupun tidak langsung dalam penelitian ini.

\section{DAFTAR PUSTAKA}

Dominey-Howes, D., Dunbar, P., Varner, J., \& Papathoma-Köhle, M. (2010). Estimating probable maximum loss from a Cascadia tsunami. Natural Hazards, (53) 43-61. Proceeding of the International Symposium on Engineering Lessons Learned from the Giant Earthquake. JAEE. P: 556-567.

Diposaptono S., \& Budiman (2006). Tsunami. Sarana Komunikasi Utama. Bogor.

http://inatews.bmkg.go.id/. Diakses tgl 23 Feb 2016 pkl.10.10 WIB.

http://www.puailiggoubat.com. Diakses tgl 23 Feb 2016 pkl.11.00 WIB.

http://www.siaga.org/. Diakses tgl 23 Feb 2016 pkl.10.07 WIB.

Ibad, M. I., \& Santosa, B. J. (2014). Pemodelan Tsunami Berdasarkan Parameter Mekanisme Sumber Gempa Bumi dari Analisis Waveform Tiga Komponen Gempa Bumi Mentawai 25 Oktober 2010, Jurnal Sains dan Seni Pomits, 3(2), 86-91.

International Workshop on Official Tsunami Hazard Map for Padang. Protocol of Padang, 25th of Augusts 2008 (2008). The Ministry of Marine Affairs and Fisheries (MoMAF) Republic of Indonesia.

Latief, H., Puspito, N. T., \& Imamura, F. (2000), Tsunami Catalog and Zoning in Indonesia, Journal of Natural Disaster, Japan.

Lifen, Z., Wulin, L., Jinggang, L., \& Qiuliang, W. (2015). Estimation og The 2010 Mentawai Tsunami Earthquake Rupture Process from Joint Inversion of Teleseismic and Strong Ground Motion Data, Geodesy and Geodynamics 2015, 6(3), 180-186.

McCloskey, J., Antonioli, A., Piatanesi, A., Sieh, K., Steacy, S., Nalbant, S., Cocco, M., Giunchi, C., Huang, J. D., \& Dunlop, P. (2008). Tsunami threat in the Indian Ocean from a future megathrust earthquake west of Sumatra. Earth and Planetary Science Letters, 265(1-2), 61-81.

Prawirodirdjo, L. (2000). A geodetic study of Sumatra and the Indonesian region: Kinematics and crustal deformation from GPS and triangulation, University of California, San Diego, San Diego.

Natawidjaja, D. H. (2003). Neotectonics of the Sumatran Fault and paleogeodesy of the Sumatran subduction zone. Ph.D Thesis. California Institute of Technology.

Natawidjaja, D. H. (2011). Geomagz. (2011). Vol. I No.4. Desember 2011. ISSN: 2088-7906. Badan Geologi Kementerian Energi dan Sumber Daya Mineral. Bandung. p.30:112.

Oktariadi, O. (2009). Penentuan Peringkat Bahaya Tsunami dengan Metode Analytical Hierarchy Process (Studi Kasus: Wilayah Pesisir Kabupaten Sukabumi). Jurnal Geologi Indonesia, 4(2), 103-116.

Satake, K., Nishimura, Y., Putra, P. S., Gusman, A. R., Sunendar, H., Fujii, Y., Tanioka, Y., Latief, H., \& Yulianto, E. (2013). Tsunami Source of the 2010 Mentawai, Indonesia Earthquake Inferred from Tsunami Field Survey and Waveform Modelling, Pure Appl. Geophys, 170, 1567-1582, doi: 10.1007/s00024-012-0536-y.

Setya, N. (2011). Pemetaan Rawan Bencana Gempa Bumi di Kabupaten Kepulauan Mentawai. Jurnal IImiah Geomatika, 19(2), $106-112$.

Setyonegoro, W., Sunardi, B., Sulastri, Nugraha, J., \& Susilanto, P. (2012). Analisis Sumber Gempabumi Pada Segmen Mentawai (Studi Kasus: Gempabumi 25 Oktober 2010), Puslitbang BMKG, Jakarta.

Shuto, N. (1993). Tsunami intensity and disasters. Dalam: Tinti, S. dan Dordrecht, $S$ (eds.) Tsunamis in the World. Kluwer Academic Publishers, h. 197-216.

Sieh, K., \& Natawidjaja, D. (2000). Neotectonics of the Sumatran fault. Indonesia. Journal of Geophysical Research, 105(B12), 295-326.

USGS. (2015). Magnitude 7.7 - Kepulauan Mentawai Region, Indonesia, (http://earthquake.usgs.gov/earthquak es/eqinthenews/2010/usa00043nx/\#d etails diakses 20 Juni 2016).

Yudichara (2006). Pemodelan Run up Tsunami di wilayah Pesisir Sukabumi. Pusat Vulkanologi dan Mitigasi Bencana Geologi, Bandung.

Yudhicara, Kongko, W., Asvaliantina, V., Suranto, Nugroho, S., Ibrahim, A., Pranowo, W. S., Kerpen, N. B., 
Krämer, K. F., \& Kunst, O. (2010). Jejak Tsunami 25 Oktober 2010 di Kepulauan Mentawai berdasarkan
Penelitian Kebumian dan Wawancara. Jurnal Lingkungan dan Bencana Geologi, 1(3), 165-181. 